\title{
PREVALENCE OF INTESTINAL PARASITES AMONG PATIENTS ATTENDED AZADI TEACHING HOSPITAL IN DUHOK CITY-KURDISTAN REGION / IRAQ
}

\author{
Manal Adil Murad "Adel Talib Mohammad Al-Saeed ${ }^{* * *}$ and Awat Abdulazeez Mustafa ${ }^{* * * *}$ \\ *Dept. of Biology, College of Science, University of Duhok, Kurdistan Region-Iraq \\ ** Dept. of Microbiology, College of medicine, University of Duhok, Kurdistan Region-Iraq \\ **** Dept. of Laboratory, Azadi Teaching Hospital, Kurdistan Region-Iraq
}

(Received: June 23, 2018, Accepted for publication: October 2, 2018)

\section{Background}

Intestinal parasitic infections are the most prevalent infections in human among developing countries, and these infections can cause gastro intestinal disorders, abdominal colic, anemia, growth retardation, and other complications such as appendicitis.

Materials and Methods

A retrospective study of five years from 2013-2017 were included, the information were obtained from the records of patients that attended Azadi-Teaching Hospital in Duhok City, Kurdistan Region. The patients were sent to the laboratory department by the physicians for stool examination. The stool samples were examined by direct wet mount smears with normal saline and lughole's iodine techniques.

$\underline{\text { Results }}$

In the current study out of 3,976 stool samples, 1,196 were positive for one or more of the intestinal parasites of the following intestinal parasites, Entamoeba histolytica, Giardia lambilia, Trichomonas hominis, Enterobious vermicularis and Hymenolypis nana.

The highest infection rate was detected in males than females which were, 656(54.8\%), 540(45.2\%), respectively. The most common parasites detected were $E$. histolytica, other parasites are reported at low rates, $(28.3 \%)$ G. lambilia $(1.1 \%)$, E. vermicularis $(0.05 \%)$ and $H . n a n a(0.1 \%)$.

Conclusion

The current study indicated that the prevalence of intestinal protozoan parasites was more than helminthes, which is considered as an important public health problem in the human population.

\section{INTRODUCTION}

$\mathbf{T}$ he intestinal parasitic infections remain as serious public health problem worldwide, because of its high occurrence in several countries and its nutritional consequences with high rates of death especially in children (Olivares and Fernández, 2012).

nfections with protozoa and helminthic parasites are estimated causing illness in 450 million in the world; most of these infections are in children (Okyay et al., 2004).

High rates of morbidity and mortality are caused by the intestinal parasites and these rates are related to the pathogenesis of the causative agents, their severity, and immune status of the host (Legesse and Erk, 2004).

The occurrence of parasitic infection differ from one region to another according to many social and economical factors, such as malnutrition, personal hygiene, population crowding, drinking unsafe water, education, and poor sanitary facilities (Mohammad et al., 2012).

There is a direct relationship between the prevalence of intestinal parasites and the socioeconomic status of the population (WHO, 2008). It is necessary to have epidemiological data about different parasitic infections in order to design control and prevention program in any endemic area (Asari et al., 2015). 
The current study was planned to provide such information on the most common intestinal parasites among population in Duhok City during the period from 2013-2017.

\section{MATERIALS AND METHODS}

The present study was a retrospective study that carried out in parasitology section Department of laboratory - Azadi Teaching Hospital - Duhok City during the period from 2013-2017. It included analysis of the registered information of the patients referred by the physicians for stool examination. About 3,976 stool samples were examined during this period. by medical laboratory technologists for the presence of parasitic stages using direct wet mount technique.

\section{RESULTS}

A total of 3,976 stool samples were examined during the period from 2013-2017, with an annual 239 cases, out of which $1,196(30.1 \%)$ were positive for one or more of the intestinal parasites.The recorded parasites included: trophozoites and cysts of Entamoeba histolytica, and Giardia lambilia, trophozoites of Trichomonas hominis, ova of Enterobious vermicularis and Hymenolypis nana.

The total rate of infection with intestinal parasites during the period of study was fluctuating as indicated in table 1. The highest infection rate was $36.7 \%$ which was reported in 2014, while the lowest was $24.3 \%$ at 2016. Regarding gender, males showed higher rates versus females (54.8\% versus $45.2 \%$ ).

Table( 1): The distribution of positive intestinal parasitic infection according to gender per year.

\begin{tabular}{ccccc}
\hline Years & $\begin{array}{c}\text { Stool samples } \\
\text { examined }\end{array}$ & Total No. and \% & $\begin{array}{c}\text { Males } \\
\text { (No. and \%) }\end{array}$ & $\begin{array}{c}\text { Females } \\
\text { ( No. and\%) }\end{array}$ \\
\cline { 3 - 5 } & 839 & $246(29.3)$ & $147(59.8)$ & $99(40.2)$ \\
\hline $\mathbf{2 0 1 3}$ & 831 & $305(36.7)$ & $157(51.5)$ & $148(48.5)$ \\
\hline $\mathbf{2 0 1 5}$ & 864 & $269(31.1)$ & $143(53.2)$ & $126(46.8)$ \\
\hline $\mathbf{2 0 1 6}$ & 602 & $146(24.3)$ & $86(58.9)$ & $60(41.1)$ \\
\hline $\mathbf{2 0 1 7}$ & 840 & $230(27.4)$ & $123(53.5)$ & $107(46.5)$ \\
\hline Total & 3976 & $1196(30.1)$ & $656(54.8)$ & $540(45.2)$ \\
& & & & \\
\hline
\end{tabular}

Regarding the rate of the infection, the highest rate $(28.3 \%)$ was with $E$. histolytica, other parasites were recorded at low rates as shown in Table 2. 
Table (2): - The rate of infection with the recorded parasites during the period from 2013-2017.

\begin{tabular}{ccccccc}
\hline Parasites species & 2013 & 2014 & 2015 & 2016 & 2017 & Total \\
\cline { 2 - 7 } & No.(\%) & No.(\%) & No.(\%) & No.(\%) & No.(\%) & No.(\%) \\
\hline E. histolytica & $232(94.3)$ & $287(94.1 \%)$ & $251(93.3)$ & $139(95.2)$ & $215(93.5)$ & $1124(93.9)$ \\
\hline G. lambilia & $8(3.3)$ & $7(2.3 \%)$ & $12(4.5)$ & $6(4.1)$ & $11(4.8)$ & $44(3.7)$ \\
\hline T.hominis & $6(2.4)$ & $7(2.3 \%)$ & $5(1.9)$ & ------ & $4(1.7)$ & $22(1.8)$ \\
\hline E.vermicularis & ------- & $2(0.7 \%)$ & ---- & ------ & --- & $2(0.2)$ \\
\hline H.nana & ------- & $2(0.7 \%)$ & $1(0.4)$ & $1(0.7)$ & ---- & $4(0.3)$ \\
\hline Total & 246 & 305 & 269 & 146 & 230 & $1196(30.1)$ \\
\hline
\end{tabular}

With respect to the distribution of intestinal parasites according to gender. Males showed higher rate of infection with $E$. histolytica during the 5 years of the study (Table 3 ).

Table (3): - The distribution of intestinal parasites among males and females according to species per year during the years 2013-2017.

\begin{tabular}{|c|c|c|c|c|c|c|c|c|c|c|}
\hline \multirow[t]{2}{*}{ Parasites } & \multicolumn{2}{|c|}{$2013(n=246)$} & \multicolumn{2}{|c|}{$2014(n=305)$} & \multicolumn{2}{|c|}{$2015(n=269)$} & \multicolumn{2}{|c|}{$2016(n=146)$} & \multicolumn{2}{|c|}{$2017(n=230)$} \\
\hline & $\begin{array}{c}\text { Male } \\
(\%) \\
\end{array}$ & $\begin{array}{c}\text { Female } \\
(\%)\end{array}$ & $\begin{array}{c}\text { Male } \\
(\%)\end{array}$ & $\begin{array}{c}\text { Female } \\
(\%)\end{array}$ & $\begin{array}{c}\text { Male } \\
(\%) \\
\end{array}$ & $\begin{array}{c}\text { Female } \\
(\%)\end{array}$ & Male (\%) & $\begin{array}{c}\text { Female } \\
(\%)\end{array}$ & Male (\%) & $\begin{array}{c}\text { Female } \\
(\%) \\
\end{array}$ \\
\hline E. histolytica & $\begin{array}{l}136 \\
(55.3) \\
\end{array}$ & $\begin{array}{l}96 \\
(39.0) \\
\end{array}$ & $\begin{array}{l}144 \\
(47.2) \\
\end{array}$ & $\begin{array}{l}143 \\
(46.9) \\
\end{array}$ & $\begin{array}{l}135 \\
50.1 \\
\end{array}$ & $\begin{array}{l}116 \\
(43.1) \\
\end{array}$ & $\begin{array}{l}81 \\
(55.5) \\
\end{array}$ & $\begin{array}{l}58 \\
(39.7) \\
\end{array}$ & $\begin{array}{l}118 \\
(51.3) \\
\end{array}$ & $\begin{array}{l}97 \\
(42.2) \\
\end{array}$ \\
\hline G. Iambilia & $\begin{array}{c}7 \\
(2.8) \\
\end{array}$ & $\begin{array}{c}1 \\
(0.4 \%) \\
\end{array}$ & $\begin{array}{c}4 \\
(1.3) \\
\end{array}$ & $\begin{array}{c}3 \\
(1 \%) \\
\end{array}$ & $\begin{array}{c}6 \\
(2.2) \\
\end{array}$ & $\begin{array}{c}6 \\
(2.2) \\
\end{array}$ & $\begin{array}{c}4 \\
(2.7) \\
\end{array}$ & $\begin{array}{c}2 \\
(1.4) \\
\end{array}$ & $\begin{array}{c}5 \\
(2.2) \\
\end{array}$ & $\begin{array}{c}6 \\
(2.6) \\
\end{array}$ \\
\hline T. hominis & $\begin{array}{c}4 \\
(1.6) \\
\end{array}$ & $\begin{array}{c}2 \\
(0.8) \\
\end{array}$ & $\begin{array}{c}5 \\
(1.6) \\
\end{array}$ & $\begin{array}{c}2 \\
(0.7) \\
\end{array}$ & $\begin{array}{c}2 \\
(0.7) \\
\end{array}$ & $\begin{array}{c}3 \\
(1.1) \\
\end{array}$ & --- & --- & --- & $\begin{array}{c}4 \\
(1.7) \\
\end{array}$ \\
\hline E. vermicularis & ------ & --- & $\begin{array}{c}2 \\
(0.7) \\
\end{array}$ & ---- & --- & ------ & ---- & ---- & ---- & ---- \\
\hline H. nana & ---- & ----- & $\begin{array}{c}2 \\
(0.7) \\
\end{array}$ & ---- & ---- & $\begin{array}{c}1 \\
(0.4)\end{array}$ & $\begin{array}{c}1 \\
(0.7) \\
\end{array}$ & ---- & ---- & ---- \\
\hline
\end{tabular}

\section{DISCUSSION}

In this study $30.1 \%$ of the examined specimens were positive for intestinal parasites. Five species of intestinal parasites were recorded with the highest rate $(36.7 \%)$ of $E$. histolytica, the remaining species were recorded at very low rates.
Furthermore males showed higher rates of infection than females (54.8\% versus $45.2 \%)$.

The rates of infection with intestinal parasites and the recorded species are variously reported in studies performed in Duhok province, other parts of Kurdistan and Iraq , furthermore, in most of these studies the highest rate of infection was with 
E. histolytica and in general the infection was more predominant in males (Mero and Hussein, 2013, Badry et al., 2014 , Mero et al., 2015 and Jameel et al., 2017).This variation in the rate and the recorded species of parasites can be due to different factors such as, sanitary condition, economic standards, the extend of hygiene application, and type of drinking water (WHO , 1992 and Orabi , 2000).

The present study is partly in agreement with a study performed in Erbil City by Saida (2016) who recorded the same species of the parasites, but with much higher rates.than the rates recorded in this study, since he reported rates of $61.24 \%$ with $E$. histolytica, followed by $26.60 \%$ with $G$. lamblia, $10 \%$ with $E$. vermiculari and $1.2 \%$ with $H$. nana

Previous studies performed in Kurdistan and other parts of Iraq, reported different rates of infection with intestinal parasites, some of them reported higher rates with protozoa, others reported higher rates with helminthes Regarding protozoa, Faraj and Koyee(2012) in Erbil, recorded high rate of infection with protozoa, with $E$. histolytica being the highest $(12.95 \%)$ followed by G. lamblia $(8.006 \%)$ and low rates with other protozoa and helminthes. Similarly Yimaz and Abdullah (2017) in Duhok and Erbil provinces, reported the highest rate with E. histolytica (26.1 and $22.8 \%$, respectively) followed by $G$. lambla $(9.5$ and $5.7 \%$, respectively). High rate of $E$. histolytica $(71.8 \%)$ followed by $G$.lambilia $(17.5 \%)$ with low rates of helminthes, A. lumbricoides 3\%, E. vermicularis $0.4 \%, H$. nana $1.2 \%$ and $S$. stercoralis $0.36 \%$ have been reported in Sharigah city of United Arab Emirates by Dash et al. (2010). Also in Ethiopia Chala (2013) recorded high rates with $E$. histolytica $(25.4 \%)$ and $G$. lambilia $(30.1 \%)$ and low rates with $E$. vermicularis $(0.2 \%)$ and $H$. nana $(1.36 \%)$.

On the other hand, Mero and Hussein(2013) in Duhok province, during 2008-2009 recorded high infection rate with G. lamblia $(11.92 \%)$, followed by E. histolytica $(10.15 \%)$, and low rates with other protozoa and helminthes. In Rmadi city, high rates of infection with G. lambilia $(90.7 \%)$, followed by E. histolytica (16.0\%) and low rates with helminthes, E. vermicularis (9.7\%)., A. lumbricoides $(1.03 \%)$, T. saginata $0.83 \%)$ and $T$. trichura $(0.32 \%)$ have been reported by
Al-Joudi and Ghazal (2005). Furthermore, in north of India, Sigh et al.(2013) observed high infection rate with G. lambilia ( $58.5 \%$ ) followed by E. histolytica (32\%) and low rate with A.lumbricoides (5.8\%), also in Tehran city in Iran, Asgari et al. (2015) examined 4,637 patients 3,450 males and 1,187 females (25.59\%), and recorded high rate of $G$. lambilia (37.9\%) followed by E.coli (26.44\%), B. hominis (11.5\%), T. hominis (12.53), E. nana (2.88\%) and E. vermicularis $(1.25 \%)$.

On the other hand, the present study disagree with studies carried out in Iraq and other countries in which higher infection rates were recorded with helminthes, such as in Nineveh province/Iraq in the years 2009-2011, high infection rates of nematodes were detected like, $T$. trichura (71.42\%) during 2009, S. stercoralis $(62.5 \%)$ in 2010 and A. duodenale (58.33\%) in 2011(AlKalak and Rahemo, 2012). In Erbil Hama and Rahemo (2014) examined 1,028 children and reported high infection rates with $E$. vermicularis $29.8 \%$ followed by $G$. lambilia $13.1 \%$ and T. hominis $1.7 \%$. In Zakho City, Jameel et al. (2017) examined the fingernails of school children and recorded high rates of helminthes eggs, such as, Enterobius vermicularis (7.76 \%), Hymenolepis nana (5.82\%), followed by cysts of E. histolytica (4.85\%), egg of Ascaris lumbricoides( $2.91 \%$ ), cysts of Giardia lamblia (2.91\%) and egg of Trichuris trichaura $(0.97 \%)$.

In Santa -Luiza state in Brazil, Delima et al. (2016) during the years from 2013-2014 examined 2,021 cases and they found that $H$. nana was more frequent (33\%) followed by $E$. histolytica (27\%), G. lambilia (3\%), and $1 \%$ for both $E$. vermiculari, and A. lumbricoides.

The variations in the prevalence rate of intestinal parasitic infections between countries and geographical areas may be due to many factors such as, socioeconomic conditions, overcrowding, hygienic and cultural habits, the ingestion of raw, unwashed vegetables and drinking of non-sterilized water especially in rural areas all these factors lead to the infection with these parasites in a given area(WHO , 1992 and Orabi , 2000). Furthermore, these parasites have simple life cycle and can be transmitted directly. The reason behind the more prevalence of infection in males than females may be due to more outdoor activities of males including 
swimming in contaminated pools, eating fast food and riding restaurants with bad hygiene (Jameel et al., 2017).

In conclusion, the present study indicated that the most common intestinal parasite was $E$. histolytica distributed among both genders during the studied years with more prevalence rate in males than females

\section{REFERENCES}

- Al-Joudi, F. S., Ghazal, A. M. (2005). The Prevalence of Intestinal Parasites in Ramadi, Iraq .Bull. Pharm. Sci., Assiut University, 28 (2), pp. 277-281.

- Al-Kalak, S., Rahemo, Z.I. (2012). Prevalence of Intestinal Nematodes of Patients Consulting Outpatient Clinics in Hospitals and Health Centers in Neinava Governorate, Iraq . Intl. J. of Molecular Zoology, 2(4), pp 39-44.

- Arani, A.Sh., Alaghehbandan, R. , Akhlaghi, L ., Shahi, M., and Lari, A.R. (2008). Prevalence of Intestinal Parasites in a Population in South of Tehran, Iran. Rev. Inst. Med. Trop. S. Paulo, 50(3), pp.145149.

- Asgari, A., Sharifi, M.D. , Anabad, H . A., Nughabi, A.Z., Fayyaz, A.F., Jafari, A.A. (2015). Evaluation of Intestinal Parasites Among Referred Patients: Report of 4637 Cases. Journal of Parasitology Diseases, 40 (4):p1640.

- Badry, A.H. , Jameel, A.Y , Mero, W.M (2014). Pathogenic Microorganisms Associated with Diarrhea in Infants and Children in Duhok Porovince, Kurdistan Region /Iraq. Journal of University of Zakho , 2( 2), pp.266-275.

- Chala, B. (2013). Prevalence of Intestinal Parasitic Infections in Mojo Health Center, Eastern Ethiopia: A 6-year(2005-2010) Retrospective Study. Epidemiology Journal , 3(119), pp. 1-5.

- Dash, N., Al-Zarouni, M. , Anwar, Kh. ,Psnigrahi, D.(2010) Prevalence of Intestinal Parasitic Infections inSharjah, UnitedArab Emirates. Human Parasitic Diseases 2010:2 pp.21-24

- De Lima, E.Q. , Santos, M.TH., De Siqueira, R.R., Filho, F.M ., Filho, R. N. (2016).
Prevalence of Intestinal Parasites in the Human Population of the City Santa Luzia - State of Paraíba, Brazil. Journal of Parasitology and Vector Biology, 8(9), pp.86-91.

- Faraj, A.and Koyee, Q. (2012). Epidemiology of Intestinal Parasites Among Food Handlers in Erbil city .Duhok Medical Journal, 6(1), pp.1-12.

- Hama, A.A., Rahemo, Z.I.(2014). Intestinal Parasitosis in Relation to Haemoglobin Concentration among Primary School Children in Erbil Province Kurdistan-Iraq, Science Journal, 1(1), pp.96-99.

- Jameel, A.Y., Isaa, A., R., Amidy, K., S., Mero, M.S., Sabri, M.A., Khidihir, M.A.(2017).Prevalence of Intestinal Parasites under Fingernails of Primary School Children in Zakho , Kurdistan Region. Science

- Journal of University of Zakho 5(1), pp25-27.

- Legesse, M. and Erko, B. (2004). Prevalence of Intestinal Parasites among School Children in a Rural Area Close to the Southeast of Lake Langano, Ethiopia. Ethiop. J. Hlth. Dev. 18 (2), pp.119-121.

- Mero, W.M. and Hussein, J.N.(2013). Prevalence of Intestinal Parasites among Children in various Localities of Duhok city and Nearby Villages. Journal of University of Zakho , 1(1), pp.189-199.

- Mero W.M. , Jameel A.Y., Amidy K.S.(2015).Microorganisms and Viruses causing Diarrhea in Infants and Primary School Children and their Relation with Age and Sex in Zakho City ,Kurdistan Region ,Iraq.

- International Journal of Research in Medical Sciences 3(11).

- Mohammad, K.A.,Mohammad, A.A., EL-nour, M.F.,Saad, M.Y., Timsah, A.G.(2012).The Prevalence and Associated Risk Factors of Intestinal Parasitic Infections among School Children living in Rural and Urban

- Communities in Damietta Governorate ,Egypt .Academic Arena.4(5), pp.90-97.

- Okyay, P., Ertug, S., Gultekin, B., Onen, O. and Beser, E.(2004). Intestinal Parasites Prevalence and Related Factors in School 
Children, a Western City Sample Turkey.BMC.publ.Hlth.,4:64.

- Olivares, J.L., Fernández, R., Fleta, J., Ruiz, M.Y. and Clavel, A. (2002). Vitamin B12 and Folic Acid in Children with Intestinal Parasiti Infection. Amer. J. 21 (2), pp.109113.

- Orabi , M.A.(2000). Epidemiological Study of Intestinal Parasites in Pre-school Children in AL-Jiftlik Area -Jordan Valley .M.Sc.Thesis , Unvi.An -Nana National, Nablus, Palastine .

- Saida, L.A. (2016). Epidemiological Study of Intestinal Parasites among Population of Erbil City, Kurdistan, Iraq . Journal of Raparin University - 3(9), pp.75-86.

- Singh, R., Singla, P., Sharma, M., Arpana, Ch. and Chaudhary, U. (2013). Prevalence of
Intestinal Parasitic Infections in a Tertiary Care Hospital in Northern India: Five year retrospective study. International Journal of Current Microbiology and Applied Sciences 2(10), pp. 112-117.

- World Health Organization - WHO (2008). The Global Burden of Disease: 2004 Update. Geneva.

- World Health Organization Statistics (1992) Communicable Disease. Epidemiology and control , 45,Geneva.

- Yilmas, H. and Abdullah, A. (2017) Prevalence of Intestinal Parasites (Entamoeba species and Giardia lambilia ) in Duhok and Erbil Cities , Northern Iraq. Journal of Microbiology and Experimentation, 4 (6),

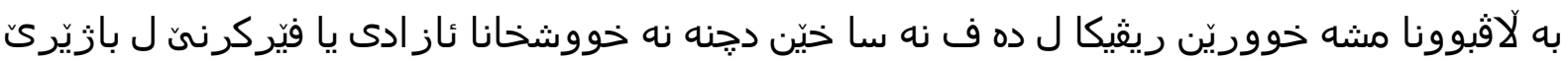

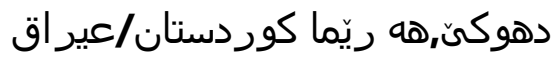

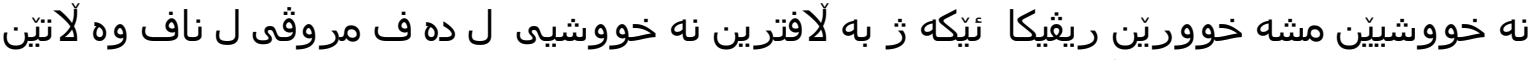

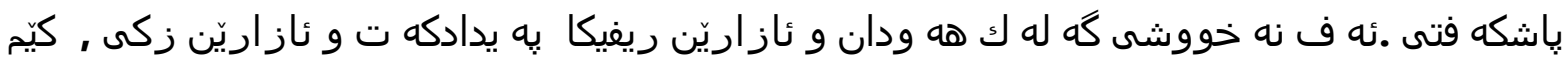

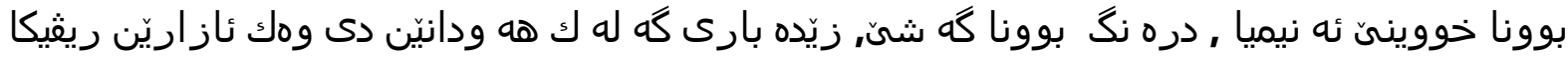

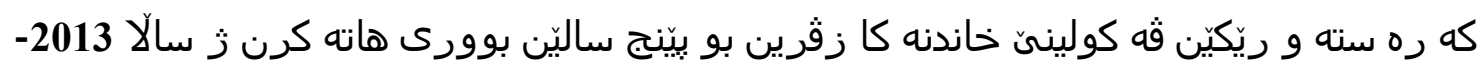

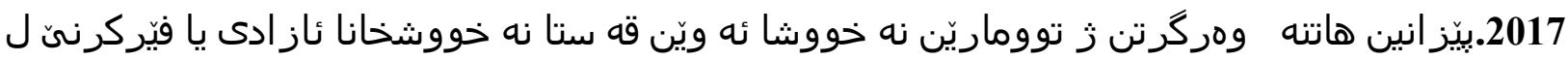

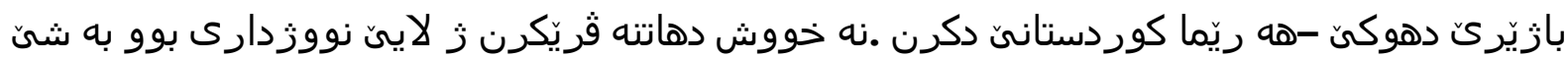

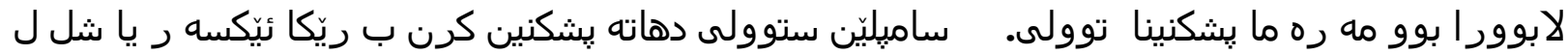

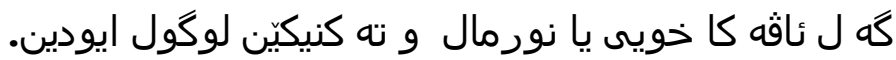

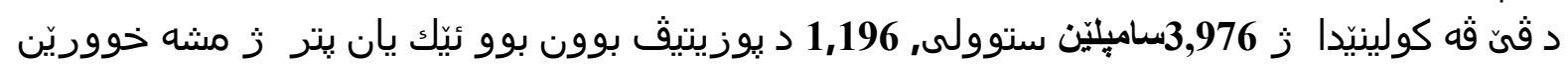

$$
\text { ئه زجام }
$$

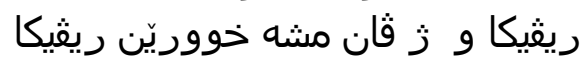

Entamoeba histolytica , Giardia lambilia ,Trichomonas hominis, Enterobious .vermicularis , Hymenolypis nana

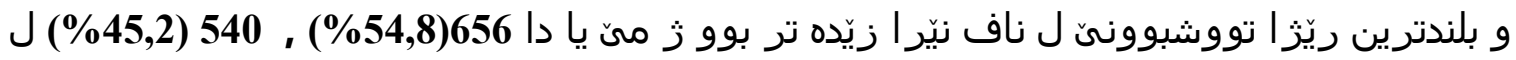
ديف يَيكّ.

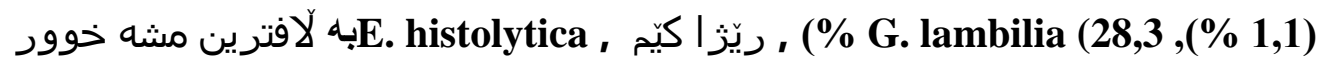




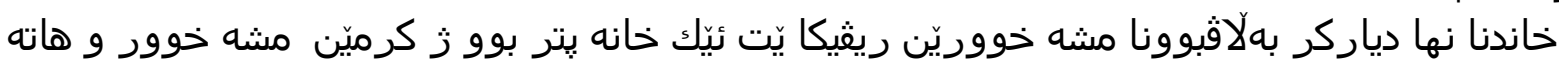

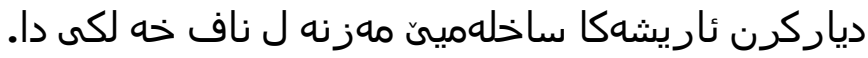

انتشار الطفيليات المعوية بين المرضى المراجعين لمستشفى ازادي التعليمي في مدينة دهوك, اقليم كوردستان / العراق لمردين

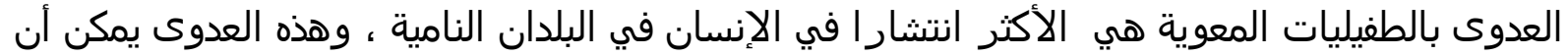

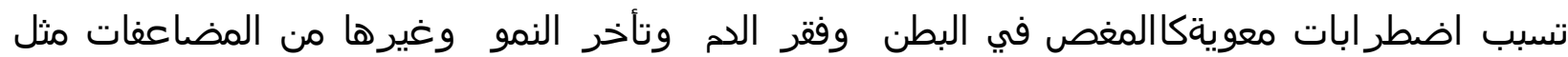

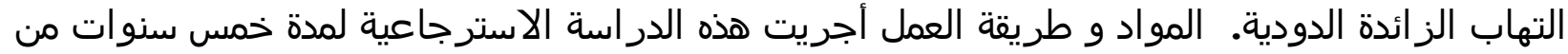

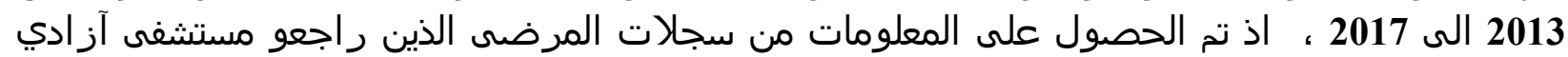

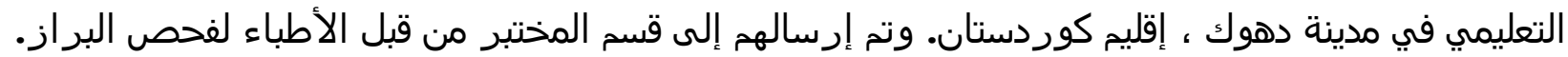

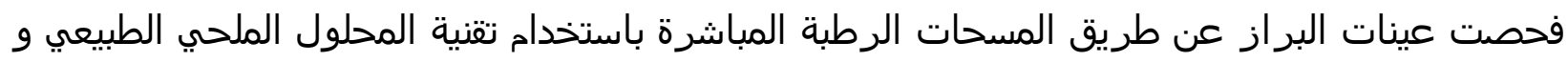
صبغة اليوداللوكولي. النتائج

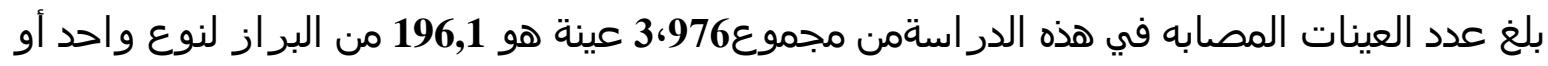

,Trichomonas hominsi,Giardia lambilia , Entamoeba histolytica

.Hymenolypis nana, , Enterobious vermicularis

فيما يخص الجنس وجدأعلى معدل إصابة في الذكورمقارنة بالإناث (54.8 ٪ و 45.2 ٪) على التوالي.

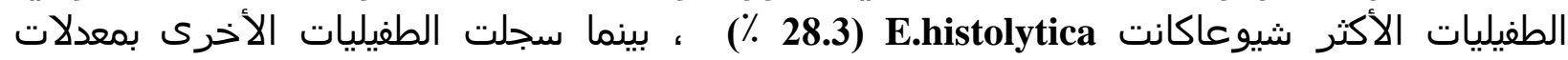

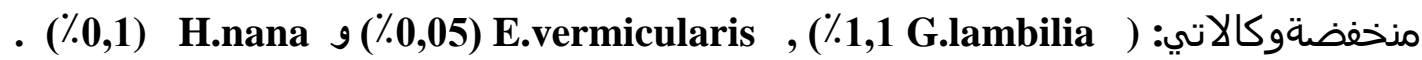

أشارت الدتتاج استة الحالية إلى أن انتشار طفيليات الاوالي المعوية كان أكثر من الديدان الطفيلية وتعتبر مشكلة صحية عامة مهمة بين السكان. 